
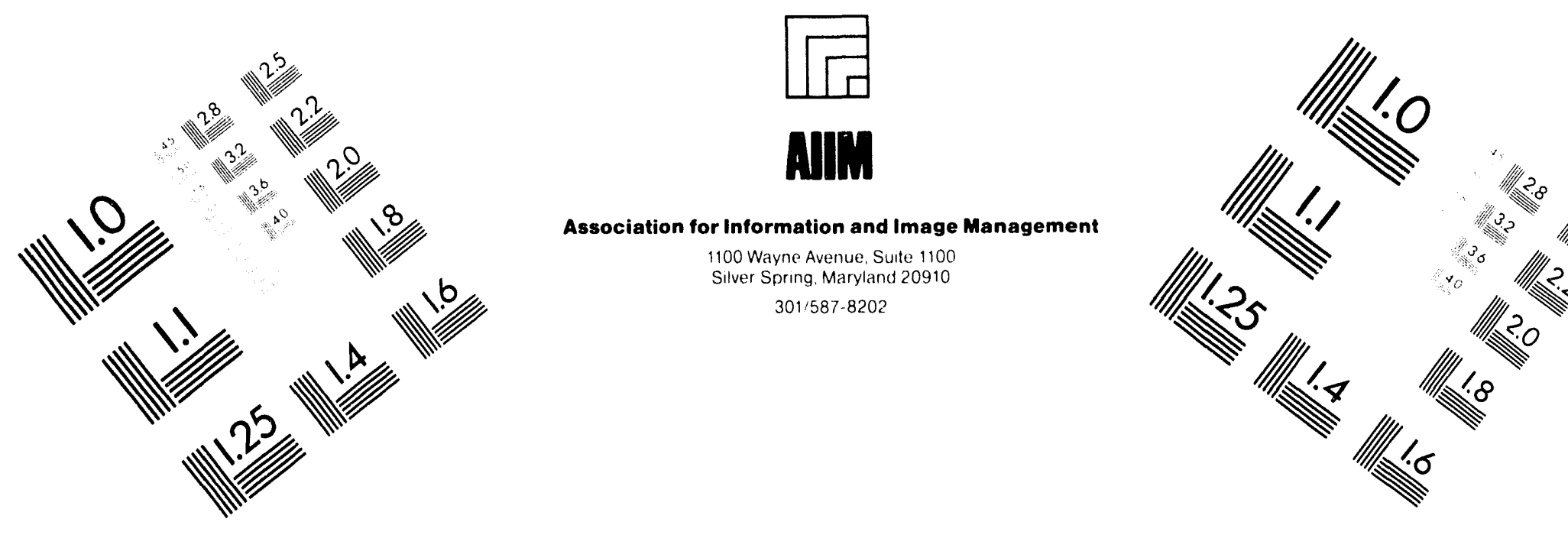

\title{
Centimeter
}

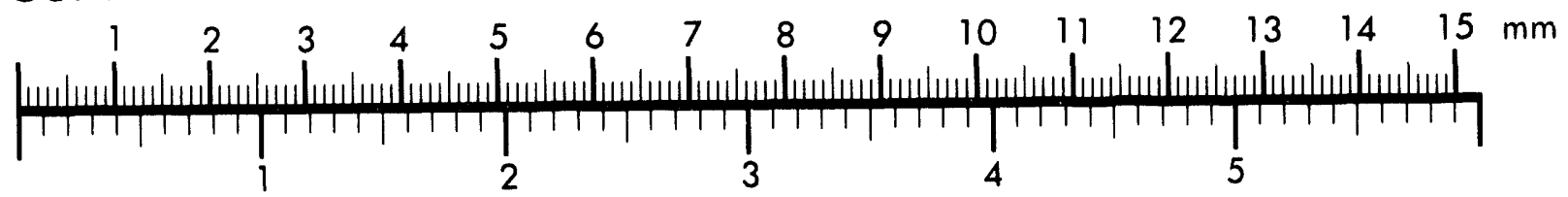

Inches
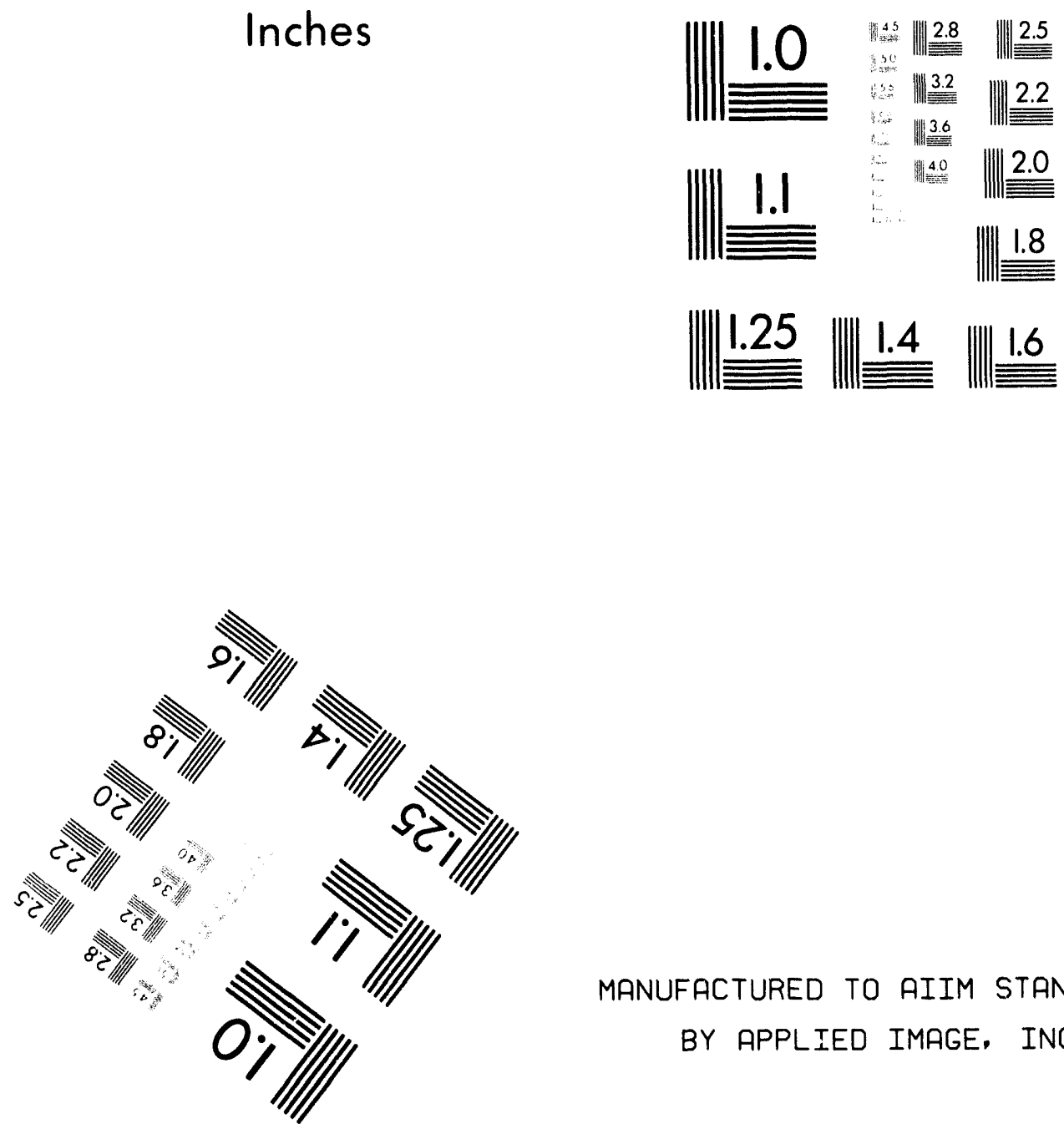

MANUFACTURED TO AIIM STANDARDS

BY APPLIED IMAGE, INC.

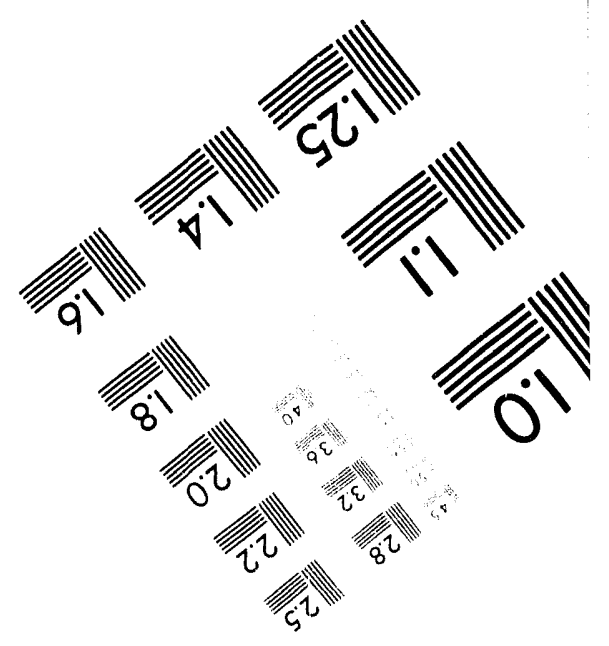



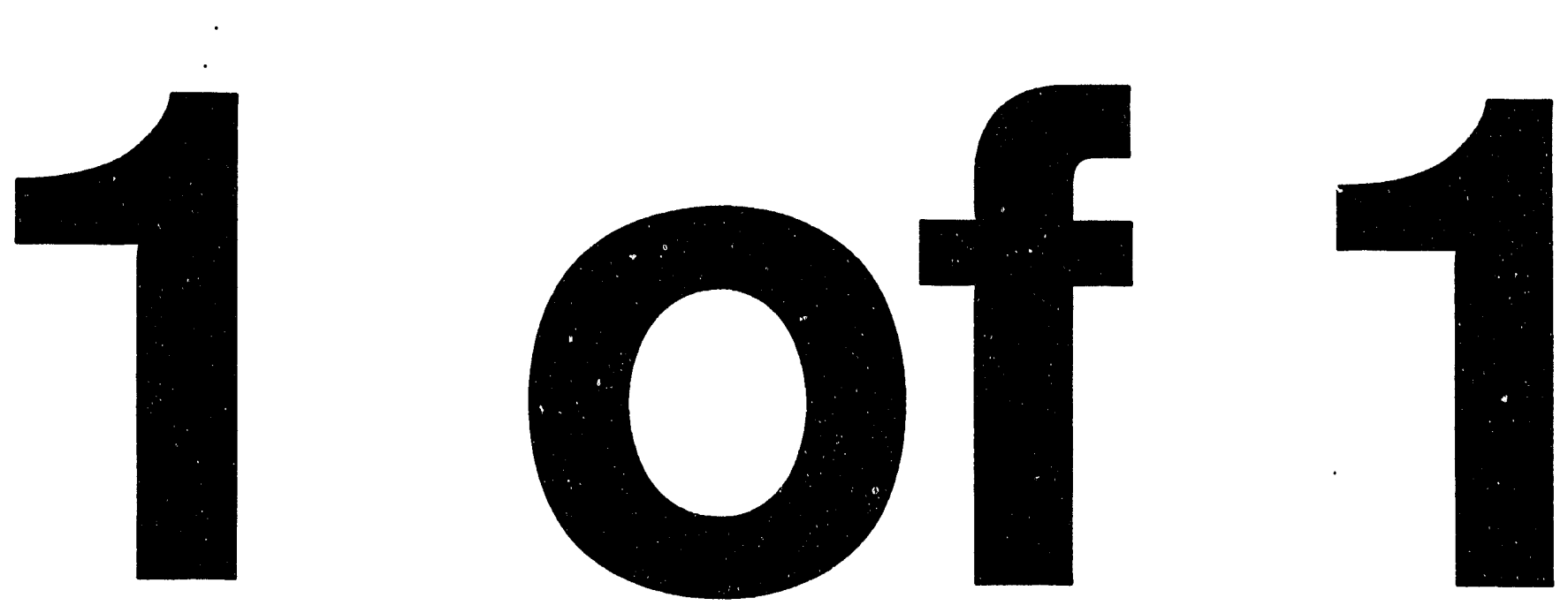


\section{Toxicity Studies of Mild Gasification Products}

\section{Quarterly Report}

Octoher - December 1993

March 1994

Work Performed Under Interagency Agreement No.: DE-AI21-89MC26018

For

U.S. Department of Energy

Office of Fossil Energy

Morgantown Energy Technology Center

Morgantown, West Virginia

By

National Institute for Occupational Safety and Health (NIOSH)

Morgantown, West Virginia 


\section{DISCLAIMER}

This report was prepared as an account of work sponsored by an agency of the United States Government. Neither the United States Government nor any agency thereof, nor any of their employees, makes any warranty, express or implied, or assumes any legal liability or responsibility for the accuracy, completeness, or usefulness of any information, apparatus, product, or process disclosed, or represents that its use would not infringe privately owned rights. Reference herein to any specific commercial product, process, or service by trade name, trademark, manufacturer, or otherwise does not necessarily constitute or imply its endorsement, recommendation, or favoring by the United States Government or any agency thereof. The views and opinions of authors expressed herein do not necessarily state or reflect those of the United States Government or any agency thereof.

This report has been reproduced directly from the best available copy.

Available to DOE and DOE contraciors from the Office of Scientific and Technical Information, 175 Oak Ridge Turnpike, Oak Ridge, TN 37831; prices available at $(615) 576-8401$.

Available to the public from the National Technical Information service, U.S. Department of Commerce, 5285 Port Royal Road, Springlie id, VA 22161; phone orders accepted at (703) 487-4650. 


\title{
Toxicity Studies of Mild Gasification Products
}

Quarterly Report

October - December 1993

Work Performed Under Interagency Agreement No.: DE-AI21-89MC26018

\author{
For \\ U.S. Department of Energy \\ Office of Fossil Energy \\ Morgantown Energy Technology Center \\ P.O. Box 880 \\ Morgantown, West Virginia 26507-0880 \\ By \\ National Institute for Occupational Safety and Health (NIOSH) \\ 944 Chestnut Ridge Road \\ Morgantown, West Virginia 26505
}

March 1994 


\section{The Genotoxicity Studies of Mild Gasification Product, Shell Oil PSIS\#830331, in Mammalian Cells}

\section{INTRODUCTION}

The major hypothesis of carcinogenesis is that malignancy is due to an alteration (mutation) of the genetic material in a somatic cell. Reactive electrophilic metabolites are generated from many chemicals by the action of endogenous mixed function oxidases. These reactive metabolites may bind to cellular macromolecules, such as DNA, and can, therefore, initiate a mutagenic or carcinogenic event. Prokaryotes and non-mammalian eukaryotes are used in mutation assays, while cultured mammalian cells are generally used for mutagenic as well as clastogenic tests examining alterations and damage to the DNA and/or chromosomes of somatic cells. One of the first mammalian cell lines used in genotoxicity studies is V79, which was derived from Chinese hamster lung cells.

According to the test plan on toxicity studdies of mild gasification products, mammalian cell in vitro assays are to be performed on selected samples displaying mutagenic activity in the Ames assay. The results of the Ames testing of the mild gasification sample Shell Oil PSIS\#330331 were negative. However, fractionation of the sample and Ames testing of the subfractions were performed per DOE request. None of the subfractions was mutagenic in the Ames assay, as has been previously reported. Assays for the induction of gene mutation, sister chromatid exchange and micronucleus formation in V79 cells have also been carried out for the sample. This paper reports the results of the mammalian cell assay.

\section{METHODS AND MATERIALS}

Sample description

PSIS\#830331 is a low-temperature coal tar obtained from Shell Oil Company, Houston, Texas.

\section{Sample preparation}

PSIS\# 830331 was melted by warming to $80^{\circ} \mathrm{C}$ in a water bath. $0.279 \mathrm{~g}$ of the sample was put into a sterile vial, and $11.6 \mathrm{ml}$ dimethyl sulfoxide (DMSO) was added. The combination was warmed to $50^{\circ} \mathrm{C}$ and sonicated in a Branson Model 3200 water bath/sonicator for 30 minutes and vortexed until a homogenous solution with a concentration of $25 \mathrm{mg} / \mathrm{ml}$ was achieved. The sample was further diluted with DMSO by one half dose in turn $(12.5,6.25$, $3.12,1.56 \mathrm{mg} / \mathrm{ml}$ etc.).

DMSO was purchased from Fisher Scientific Company, Fair Lawn, New Jersey. $\mathrm{N}$-methyl-N'-nitro-N-nitrosoguanidine (MNNG), used as a postive control, was purchased from Aldrich Chemical Company, Inc., Milwaukee, Wisconsin. 


\section{Cell line and culture conditions}

The Chinese hamster lung fibroblast (V79) cell line was kindly supplied by Dr. C.C. Chang (Michigan State University). The cells were certified to be free of mycoplasma contamination by the standard MycoTect assay (Gibco, Gaithersburg, Maryland). Stock cultures were maintained in a monolayer in a $75 \mathrm{~cm}^{2}$ flask with growth medium - minimum essential medium (MEM, Gibco) supplemented with $10 \%$ heat-inactivated fetal bovine serum (FBS, Gibco), $100 \mathrm{U} / \mathrm{ml}$ penicillin and $100 \mu \mathrm{g} / \mathrm{ml}$ streptomycin (Gibco) - at $37^{\circ} \mathrm{C}$ and $100 \%$ humidity in a $5 \% \mathrm{CO}_{2}$ atmosphere. The cells were passaged every 3-4 days by treatment with a trypsin-EDTA solution (Gibco) in phosphate buffered saline (PBS) to prevent the cultures from becoming confluent. Working cultures of this cell line were maintained under the same conditions for the described assays.

Assay procedures

\section{HGPRT gene mutation assay}

Hypoxanthine-guanine-phosphoribosyl transferase (HGPRT) is an enzyme, consisting of 2-4 protein subunits that catalyzes the salvage of hypoxanthine and guanire by the conversion of these purines to the corresponding nucleoside-5-monophosphates (necessary components of DNA required for cell division and culture growth) upon reaction with phosphoribosyl pyrophosphate. The enzyme also catalyzes the conversion of the purine analogs (poisons) 6-mercaptopurine (MP), 6-thioguanine (TG), and 8-azaguanine (AG) into their lethal nucleoside-5-monophosphate forms. V79 cells with mutations that inactivate the product of the HGPRT gene locus, on the $X$ chromosome in humans and rodents, will grow in medium containing the poisonous purine analogs that kill cells with normal HGPRT levels, because they can't metabolize exogenous purines or their deadly analogs. In order to survive, however, these mutants must rely on their ability to synthesis the required purines by a de novo pathway. Aminopterin is a substance that inhibits the de novo synthesis of nucleotides, making a cell dependent on exogenous hypoxanthine, glycine and thymidine. When cultured in medium containing hypoxanthine, aminopterin, thymidine and glycine (HAT medium), mutated V79 cells die because they cannot utilize the exogenous hypoxanthine or synthesize their own purines via the de novo pathway. V79 clones with a mutation inactivating the HGPRT gene product are selected by both 6-thioguanine resistance (TG') and an inability to survive in HAT medium. Induction of the $\mathrm{TG}^{\mathrm{r}}$ mutation will be carried out according to the protocol recommended by E.R. Nestmann et al. (1991), based on a survey of current practice in genotoxicity testing laboratories.

Five chemical concentrations, a solvent control, and a positive control were tested with and without $\mathrm{S} 9$ metabolic activation. $5 \times 10^{5}$ cells were seeded in $25 \mathrm{~cm}^{2}$ flasks containing $5 \mathrm{ml}$ growth medium and incubated at $37^{\circ} \mathrm{C}$ in a humid atmosphere of $5 \% \mathrm{CO}_{2}$. Twenty-four hours later, the medium was replaced with treatment medium containing $4.5 \mathrm{ml} 5 \%$ FBS medium and $0.5 \mathrm{ml} \mathrm{S9}$ mixture (for metabolic activation) or $5 \mathrm{ml} 5 \% \mathrm{FBS}$ medium without S9 (for testing direct-acting mutagens), and $50 \mu \mathrm{l}$ of the Shell Oil sample. After a 3-hour exposure, the cells were rinsed twice with PBS, trypsinized, and replated in two $100 \mathrm{~mm}$ dishes containing $10 \mathrm{ml}$ MEM at $2.5 \times 10^{5}$ cells/dish for the mutation studies and in six 
$60 \mathrm{~mm}$ dishes containing $5 \mathrm{ml}$ MEM at 100 cells/dish for measurement of cell survival. Following a 7-day incubation period, the cultures in the $60 \mathrm{~mm}$ dishes were fixed, stained and counted. Cell survival relative to the untreated controls (i.e., the relative colony forming efficiency; CFE) was determined for each dose level tested; relative CFE = (the number of colonies with treatment/the number of colonies in the control) $\times 100 \%$. At least four treatment concentrations which gave relative CFEs ranging between 10 and $100 \%$ were tested.

The cultures in the $100 \mathrm{~mm}$ dishes, prepared for the mutation studies, were also incubated at $37^{\circ} \mathrm{C}$ for an expression period of 7 days; during which time the cells were passaged two or three times. After a week, the cells were washed with PBS and trypsinized in preparation for plating another CFE and expression assay. 100 cells/dish were seeded in $60 \mathrm{~mm}$ dishes containing $5 \mathrm{ml}$ MEM. Six dishes per treatment were used. These cultures were fixed and stained with Giemsa after 7 days to determine the absolute CFE of the treated cells. Absolute CFE = (the number of colonies formed/the number of cells plated) $\times 100 \%$. Approximately $2.5 \times 10^{5}$ cells were seeded in $100 \mathrm{~mm}$ dishes (six per treatment) containing $10 \mathrm{ml}$ of selection medium (94\% hypoxanthine-free MEM, 5\% dialyzed FBS, $1 \% 1 \mathrm{mM}$ 6-thioguanine solution). The selection plates were incubated for 10 days, after which the colonies were fixed, stained, and counted by eye. The criterion for minimum acceptable colony size was a diameter of $0.5 \mathrm{~mm}$ or greater or : ninimum of 50 cells per colony. Mutation frequency (MF) = number of mutant colonies/(total cells seeded on all replicate plates $\mathbf{x}$ absolute CFE). Solvent and MNNG were tested simultaneously as solvent and positive controls, respectively.

\section{Sister Chromatid Exchange (SCE) Assay}

The in vitro SCE assay is frequently used for evaluating the potential of chemicals to induce genetic damage. Although the molecular basis of SCE formation remains unknown, SCEs represent the breakage of 4 stands of DNA ( 2 double helices), a switch of those strands between chromatids of the same chromosome, and the rejoining of those strands in their new location. It is important to know whether the breakage and rejoining events occur faithfully (i.e. without producing any modification in the genetic code). Several studies have demonstrated that the frequency of SCE increases when cells are exposed to known mutagens and carcinogens.

The method followed is that described by Perry and Wolff (1974). Approximately $6 \times 10^{5}$ V79 cells were seeded into $100 \mathrm{~mm}$ dishes containing $10 \mathrm{ml}$ growth medium and incubated at $37^{\circ} \mathrm{C}$. Twenty-four hours later, the medium was removed and replaced with treatment medium containing $9 \mathrm{ml} 5 \%$ FBS medium and $1 \mathrm{ml} \mathrm{S9} \mathrm{mixture,} \mathrm{or} 10 \mathrm{ml} 5 \%$ FBS medium without S9 treatment. The 4-6 concentrations of the Shell Oil sample were determined by the survival test included in the gene mutation assay. After a 3-hour treatment, the cells were washed with PBS, trypsinized, and reseeded into two dishes per treatment with $10 \mathrm{ml}$ fresh medium. One dish was used for micronucleus induction (see below); the other for the SCE assay. Solvent and positive (MNNG) controls were run concurrently with each experiment. 
For the SCE assay, 5-bromo-2'-deoxyuridine (BrdU, Sigma) was added to each dish to a final concentration of $20 \mu \mathrm{M}$, followed by a 28-30-hour incubation in the dark. Two hours before harvesting, colcemid was added at a final concentration of $1 \mu \mathrm{M}$. The cells were harvested by trypsinization, washed by centrifugation, resuspended in $75 \mu \mathrm{M} \mathrm{KCl}$ hypotonic solution for $20 \mathrm{~min}$ at $37^{\circ} \mathrm{C}$, and fixed 3 times in a 3:1 mixture of methanol-acetic acid. Two drops of the cell suspension was dropped onto a cold, wet slide which was then waved through a flame. After aging overnight, the slides were stained using the fluorescenceGiemsa method (Perry and Wolff, 1974). One hundred metaphase cells from each treatment were counted for replicative index determination, while 30 cells having 20-23 welldistinguished and well-spread chromosomes were scored for SCEs. The results are expressed as the mean number of SCEs per metaphase \pm S.D. The grouped $t$ test was used to compare the average frequencies of SCEs induced by the Shell Oil sample.

\section{Micronucleus (MN) assay}

Micronuclei are small chromatin-containing bodies arising from acentric chromosomal fragments or whole chromosomes that failed to be incorporated into the daughter nuclei following mitosis. The presence of $\mathrm{MN}$ can be taken as an indication of chromosome breakage and/or spindle dysfunction (Krishna et al., 1984). Treatment of V79 cells with the Shell Oil sample and preparation of the cell suspension after exposure are described in the procedures for the SCE assay. After treaiment, cells were incubated for $24 \mathrm{hrs}$, harvested by trypsinization, washed by centrifugation, and resuspended in growth medium to an optimum density. Slides were prepared using cytocentrifugation. An aliquot of cell suspension $(50-75 \mu \mathrm{l})$ was loaded into a chamber, and the cells were pelleted onto slides at $600 \mathrm{rpm}$ for $7 \mathrm{~min}$, fixed with methanol, and stained with Diff-Quik stain (Dage Diagnostics, Aquada, Puerto Rico). The frequency of micronucleated cells in each treatment is based on 3000 cells scored. The criteria used to scored MN were the following: (1) the diameter of micronucleus must be no larger than one-fifth of the main nucleus; (2) the staining intensity must be equal to that of nucleus; (3) the micronucleus must be located in the cytoplasm; and (4) there must be no contact with the main nucleus (Roberts et al., 1986). The results are expressed as an average number of cells with MN per 1000 cells \pm S.D. Statistical analysis is based on the Chi-square test.

\section{RESULTS AND DISCUSSION}

Results of the cytotoxicity testing of the Shell Oil sample indicate that the test chemical significantly reduced the survival of cultured V79 cells at the concentration range of 15.6 $94.0 \mu \mathrm{g} / \mathrm{ml}$ without $\mathrm{S} 9$ activation (Table 1). There was less killing effect induced by the test sample under the conditions tested in the presence of S9. This may be due to an inactivation of the cytotoxicity by the metabolic enzymes in the S9.

Results of the HGPRT gene mutation assay are shown in Table 2. V79 cells were exposed to the Shell Oil sample at doses as high as $94.0 \mu \mathrm{g} / \mathrm{ml}$, both with and without S9 activation; however, none of the concentrations tested significantly increased the frequency of $\mathrm{TG}^{r}$ 
mutants. No dose response or minimum of a three-fold increase over the spontaneous level was noted. Therefore, no evidence of induction of gene mutations was noted under the conditions tested. The study was repeated, and the results were confirmed.

The frequencies of MN and SCE induced by the Shell Oil sample at various concentrations are presented in Tables 3 and 4, respectively. A significan increase in the frequency of MN formation was seen when cells were treated with the Shell Oil sample at concentrations of 62.5 and $94.0 \mu \mathrm{g} / \mathrm{ml}$, both with and without S9 metabolic activation. The Shell Oil sample induced a significant increase in the SCE frequency throughout the dose range tested (15.6 $94.0 \mu \mathrm{g} / \mathrm{ml}$ ). The observed increases in both $\mathrm{MN}$ and SCF are dose-dependent and statistically significant.

These results indicate that the Shell Oil sample can cause DNA damage, chromosome breakage and/or spindle fiber dysfunction in V79 cells with and without metabolic activation by S9. Therefore, it appears that direct-acting genotoxic agents are present in the Shell Oil sample, although it may also contain indirect-acting mutagens.

\section{REFERENCES}

Krishna, G., M.L. Kropo, and J.C. Theiss (1989) Use of the cytokinesis-block method for the analysis of micronuclei in V79 Chinese hamster lung cells: results with mitomycin C and cyclophosphamide, Mutation Res, 222:63-69.

Nestmann, E.R., K.L. Brillinger, J.P.W. Gilman, C.J. Rudd, and S.H.H. Swierenga (1991) Recommended protocols based on a survey of current practice in genotoxicity testing laboratories: II. Mutation in Chinese hamster ovary, V79 Chinese hamster lung and L5178Y mouse lymphoma cells, Mutation Res., 246:255-284.

Perry, P. and S. Wolff (1974) New Giemsa method for staining of sister chromatids, Nature, 251:156-159.

Roberts, C.J., G.R. Morgan, and P.D. Holt (1986) A critical comparison of the micronucleus yield from high and low LET irradiation of plateau-phase cell populations, Mutation Res, 160:237-242. 


\section{Table 1. Cytotoxicity of Shell Oil PSIS\#830331 to V79 Cells}

\begin{tabular}{|c|c|c|c|c|c|}
\hline \multirow{3}{*}{$\begin{array}{l}\text { Chemical } \\
\text { treatment }\end{array}$} & \multirow{3}{*}{$\begin{array}{l}\text { Concentration } \\
(\mu \mathrm{g} / \mathrm{ml})\end{array}$} & \multicolumn{4}{|c|}{ Relative colony forming efficiency ${ }^{b}$} \\
\hline & & $-\mathrm{S} 9$ & & $+\mathrm{S} 9$ & \\
\hline & & Mean \pm SD & $\%$ & Mean \pm SD & $\%$ \\
\hline \multirow[t]{6}{*}{ Shell Oil } & $0.0^{\mathrm{c}}$ & $96 \pm 13$ & 100 & $110 \pm 8$ & 100 \\
\hline & 7.8 & $123 \pm 7$ & 128 & $116 \pm 7$ & 105 \\
\hline & 15.6 & $82 \pm 8$ & 85 & $96 \pm 7$ & 87 \\
\hline & 31.2 & $75 \pm 12$ & 78 & $110 \pm 3$ & 100 \\
\hline & 62.5 & $63 \pm 8$ & 65 & $81 \pm 3$ & 73 \\
\hline & 94.0 & $26 \pm 5$ & 27 & $61 \pm 12$ & 55 \\
\hline MNNG $^{d}$ & 1.0 & $60 \pm 6$ & 63 & $116 \pm 9$ & 105 \\
\hline
\end{tabular}

$\begin{array}{ll} & 3 \mathrm{~h} \text { exposure } \\ { }^{\mathrm{b}} \text { Relative CFE }=\frac{\text { Absolute CFE (treatment) }}{\text { Absolute CFE (control) }} \times 100 & { }^{\mathrm{c}} \mathrm{DMSO} \text { solvent control } \\ { }^{\mathrm{d}} \mathrm{N} \text {-methyl- } \mathrm{N} \text { '-nitro-N-nitrosoguanidine }\end{array}$

Table 2. Frequency of 6-thioguanine Resistant Mutants in V79 Cells Treated with Shell Oil PSIS\#830331

\begin{tabular}{|c|c|c|c|c|c|}
\hline \multirow[t]{2}{*}{$\begin{array}{l}\text { Chemical } \\
\text { treatment }^{\mathrm{a}}\end{array}$} & \multirow[t]{2}{*}{$\begin{array}{c}\text { Concentration } \\
(\mu \mathrm{g} / \mathrm{ml})\end{array}$} & \multicolumn{2}{|c|}{$\begin{array}{l}\text { Relative Survival } \\
(\%)\end{array}$} & \multicolumn{2}{|c|}{$\begin{array}{c}\text { Mutants per } 10^{5} \\
\text { Survivors (Mean } \pm \text { SD) }\end{array}$} \\
\hline & & $-\mathrm{S} 9$ & $+\mathrm{S} 9$ & -59 & $+\mathrm{S} 9$ \\
\hline Shell Oil & $\begin{array}{r}0.0^{b} \\
7.8 \\
15.6 \\
31.2 \\
62.5 \\
94.0\end{array}$ & $\begin{array}{r}100 \\
128 \\
85 \\
78 \\
65 \\
27\end{array}$ & $\begin{array}{r}100 \\
105 \\
87 \\
100 \\
73 \\
55\end{array}$ & $\begin{array}{l}1.9 \pm 0.2 \\
0.5 \pm 0.5 \\
0.2 \pm 0.2 \\
0.1 \pm 0.2 \\
0.9 \pm 1.5 \\
0.2 \pm 0.3\end{array}$ & $\begin{array}{l}0.6 \pm 0.4 \\
2.0 \pm 0.8 \\
0.1 \pm 0.1 \\
0.2 \pm 0.2 \\
0.1 \pm 0.2 \\
0.2 \pm 0.3\end{array}$ \\
\hline $\mathrm{MNNG}^{\mathrm{c}}$ & 1.0 & 63 & 105 & $20.5 \pm 1.7$ & $92.1 \pm 0.4$ \\
\hline
\end{tabular}


Table 3. Frequency of Micronuclei in V79 cells Treated with Shell Oil PSIS\#830331

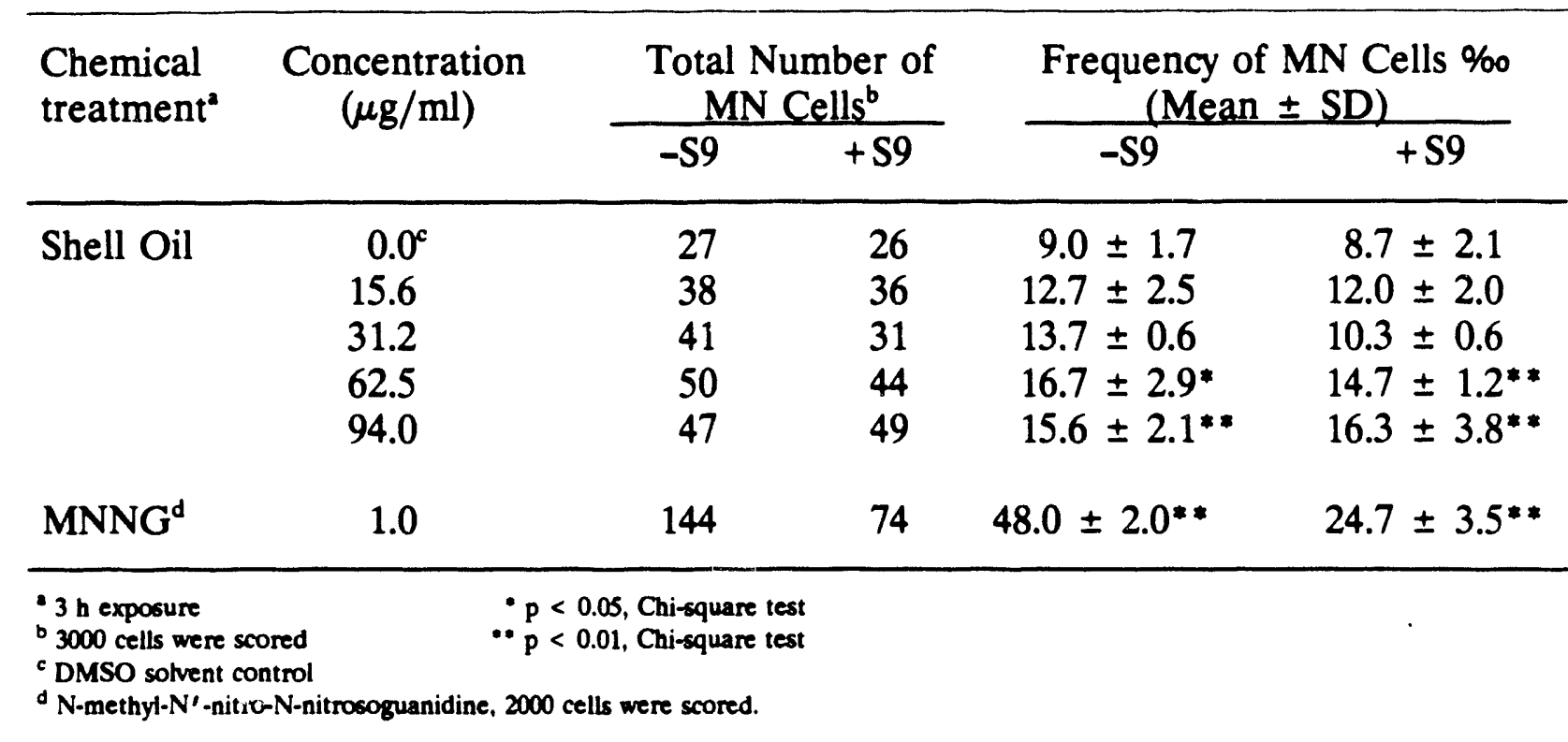

Table 4. Frequency of Sister Chromatid Exchange in V79 Cells Treated with Shell Oil PSIS\#830331

\begin{tabular}{|c|c|c|c|c|c|}
\hline \multirow[t]{2}{*}{$\begin{array}{l}\text { Chemical } \\
\text { treatment }\end{array}$} & \multirow[t]{2}{*}{$\begin{array}{c}\text { Concentration } \\
(\mu \mathrm{g} / \mathrm{ml})\end{array}$} & \multicolumn{2}{|c|}{$\begin{array}{c}\text { SCE / Cell } \\
(\text { Mean } \pm \text { SD) }\end{array}$} & \multicolumn{2}{|c|}{$\begin{array}{c}\text { Replication } \\
\text { Index }\end{array}$} \\
\hline & & $-\mathrm{S9}$ & $+\mathrm{S} 9$ & $-S 9$ & +59 \\
\hline Shell Oil & $\begin{array}{r}0.0^{c} \\
15.6 \\
31.2 \\
62.5 \\
94.0\end{array}$ & $\begin{array}{c}7.3 \pm 2.1 \\
10.3 \pm 3.9^{* *} \\
11.9 \pm 3.5^{* *} \\
13.3 \pm 4.5^{* *} \\
\text { too toxic }\end{array}$ & $\begin{aligned} 7.2 & \pm 2.2 \\
8.8 & \pm 2.8^{*} \\
9.8 & \pm 2.8^{* *} \\
12.6 & \pm 4.3^{* *} \\
15.3 & \pm 4.7^{* *}\end{aligned}$ & $\begin{array}{l}1.97 \\
2.00 \\
1.93 \\
1.69 \\
\text { toxic }\end{array}$ & $\begin{array}{l}1.97 \\
1.97 \\
1.97 \\
1.93 \\
1.62\end{array}$ \\
\hline $\mathrm{MNNG}^{\mathrm{d}}$ & 1.0 & $48.8 \pm 10.2^{* *}$ & $36.4 \pm 10.4^{* *}$ & 1.90 & 1.81 \\
\hline
\end{tabular}


, 


\section{Mutagenicity of MRE 1 Subfractions in the Ames Assay}

\section{INTRODUCTION}

Mild gasification of coal is a technology being developed by the United States Department of Energy (DOE) and private industry with the hope that a cleaner method of coal use can help meet future energy needs. As the technology develops and its commercial use becomes a more viable possibility, efforts are being made to study the safety and possible toxicity of the mild gasification products. DOE and the National Institute for Occupational Safety and Health (NIOSH) are cooperating through an interagency agreement to examine some of these products for their genotoxic potential.

The Ames Salmonella/microsomal assay (Maron and Ames, 1983) is widely used as a shortterm test for the detection of possible genotoxic agents and potential carcinogens. Bacterial tester strains used in the Ames assay contain specific mutations (frameshift or base pair substitution) that cause the bacteria to be dependent on growth medium containing the amino acid histidine. The mutagenic activity of a test substance is measured by the number of reverse mutations eliminating the histidine requirement. DNA mutation is generally accepted to be involved in the initiation stage of carcinogenesis; therefore, the Ames assay has often been used as the first tier of testing in the evaluation of long-term health risks associated with exposure to certain chemicals. NIOSH has used this assay to study the mutagenicity of ten mild gasification products. Several of those samples, including MRE 1, have been found to be mutagenic. It is difficult to know which group of chemicals is responsible for the mutagenic activity in complex mixtures. Therefore, such mixtures are often separated by organic solvents into subfractions for testing of mutagenic potentials. This report details the results of testing the subfractions of MRE 1.

\section{MATERIALS AND METHODS}

\section{Sample description}

MRE 1 has a liquid/tar consistency and a boiling point of $216^{\circ} \mathrm{F}$. The sample was made from a 50:50 mix of low- and high-sodium Montana coal and was obtained from Maumee Research and Engineering (MRE).

\section{Chemicals}

Positive controls:

2-aminoanthracene (2AA), a chemical mutagen which requires metabolic activation (+S9), and trinitrofluorenone (TNF), a direct-acting mutagen (-S9), were used in the assay system at a final concentration of 2.5 and $0.5 \mu \mathrm{g} /$ plate, respectively. Both chemicals were purchased from Aldrich Chemical Company, Milwaukee, Wisconsin. 
Solvent control:

Dimethylsulfoxide (DMSO; sterile, spectrophotometric grade) was purchased from EM Science, Cherry Hill, New Jersey.

\section{Sample preparation}

Fractionation

The fractionation of MRE 1 was performed by Dr. Joseph Ma of the West Virginia University School of Pharmacology. Briefly, the sample was dissolved in ethyl acetate and extracted with sodium hydroxide $(\mathrm{NaOH})$. The $\mathrm{NaOH}$ layer was neutralized with $\mathrm{HCl}$ and the precipitate (the acidic fraction) was collected. The ethyl acetate layer was extracted again; this time with $\mathrm{HCl}$. The acidic layer was separated and neutralized with sodium bicarbonate. The precipitate, the basic fraction, was collected. The remaining ethyl acetate layer now contained only the neutral fractions of the sample. Crude silica gel was added to the solution. After stirring, the solvent, ethyl acetate, was removed under reduced pressure. An affinity column was prepared and eluted with hexane and cyclohexane to collect the nonpolar neutral fraction. The column was then eluted with cyclohexane/ethyl acetate to collect the polar neutral fraction. The solvents were removed from each fraction before testing was done. The fractions were dissolved in DMSO for the Ames assay. Care was taken to insure that homogeneous mixtures were used while preparing dilutions and during testing.

\section{DMSO Solvation:}

Each fraction was dissolved in pure DMSO to the desired concentrations. The mixture was heated to $50^{\circ} \mathrm{C}$ and sonicated in a Branson model 3200 water bath/sonicator for 30 minutes to facilitate homogenization. The positive controls were prepared in a manner similar to the sample to ensure consistent experimental design.

\section{Microsuspension Assay}

The mutagenicity of MRE 1 was determined using the microsuspension variant of the Ames Salmonella/microsomal assay system (Maron and Ames, 1983) that can be used when the amount of sample is very small. This test is more sensitive than the standard protocol (Kado et al., 1983), partially due to the fact that a more concentrated solution (20X) of bacteria is used. Tester strains TA98 and TA100 (kindly provided by Dr. B.N. Ames of the University of California at Berkeley) were grown and centrifuged to a density of approximately $4 \times 10^{9}$ cells/ml nutrient broth. A $25 \mu \mathrm{l}$ aliquot of the bacterial solution was added to each test tube used in the assay. To determine the metabolic activation requirements of the sample, each dose was tested both with and without S9 metabolic activation mixture (prepared from liver preparations of Arochlor-1254-treated male Wistar rats). Each of these treatments was tested in triplicate. The + S9 treatments received $65 \mu \mathrm{l}$ aliquots of the $\mathrm{S} 9 \mathrm{mix}$, while $-\mathrm{S} 9$ treatments received $65 \mu \mathrm{l}$ physiological saline. $10 \mu \mathrm{l}$ of chemical solution was added to the test tubes which were then incubated at $37^{\circ} \mathrm{C}$ for $30 \mathrm{~min}$ on a rotary shaker. After the incubation $2.5 \mathrm{ml}$ molten top agar was added to each tube, 
the mixture was poured onto plates, and the plates were incubated at $37^{\circ} \mathrm{C}$ for $48 \mathrm{~h}$. The large colonies that survived and grew were mutated, histidine-independent revertants. Three readings of each plate were scored on an automatic colony counter. The criteria for positive test results consist of revertant counts at least twice that of the solvent control and a clear dose-related increase in mutagenic activity.

\section{RESULTS AND DISCUSSION}

The sample MRE 1 displayed mutagenic activity only in the nonpolar neutral subfraction. This fraction was mutagenic on both tester strains, TA98 and TA100, in the presence and absence of S9 metabolic activation. Activity was weaker in TA100, strongest in TA98 with S9. These results were confirmed when the assay was repeated.

The histidine dependence in TA98 is due to a frameshift mutation, which shifts the reading frame of the genetic code, while the histidine dependence in TA100 is due to a non-specific base-pair substitution. The reversion of either mutation requires another event of the same type of mutation, so the evidence of mutagenic activity in TA98 and TA100 indicates that the nonpolar neutral sample most likely contains frameshift mutagens, but may also contain base-pair substitution mutagens. The fact that the activity is present both with and without S9 suggests that the nonpolar neutral fraction contains direct and possibly indirect mutagenic agents.

\section{REFERENCES}

Ma, C.Y., C.H. Ho, R.B. Quincy, M.R. Guerin, T.K. Rao, B.E. Allen and J.L. Epler (1983) Preparation of oils for bacterial testing, Mutat. Res., 118:15-24.

Maron, D.M. and B.N. Ames (1983) Revised methods for the Salmonella mutagenicity test. Mutat. Res, 113:173-215.

Kado, N.Y., D. Langley and E. Eisenstadt (1983) A simple modification of the Salmonella liquid incubation assay: increased sensitivity for detecting mutagens in human urine, Mutat. Res., 121:25-32. 
TABLE I

Mutagenicity Testing of the Subfractions of MRE 1

\begin{tabular}{|c|c|c|c|c|c|}
\hline \multirow[b]{3}{*}{ Sample } & \multirow{3}{*}{$\begin{array}{c}\text { Concentration } \\
\mu \mathrm{g} / \mathrm{pl}\end{array}$} & \multicolumn{4}{|c|}{ Average Number of Revertant Colonies per Plate } \\
\hline & & \multicolumn{2}{|c|}{ TA 98} & \multicolumn{2}{|c|}{ TA 100} \\
\hline & & - S9 & $+\mathrm{S} 9$ & - S9 & + S9 \\
\hline \multirow[t]{5}{*}{ Basic } & $0^{A}$ & 23 & 27 & 100 & 98 \\
\hline & 62.5 & 26 & 34 & 77 & 87 \\
\hline & 125 & 23 & 23 & 83 & 94 \\
\hline & 250 & 26 & 24 & 88 & 95 \\
\hline & 500 & 20 & 23 & 74 & 85 \\
\hline \multirow[t]{5}{*}{ Acidic } & $0^{A}$ & 23 & 27 & 100 & 98 \\
\hline & 31.2 & 30 & 41 & 100 & 110 \\
\hline & 62.5 & 30 & 43 & 119 & 98 \\
\hline & 125 & 38 & 47 & 115 & 98 \\
\hline & 250 & $49^{*}$ & 48 & 132 & 114 \\
\hline \multirow{6}{*}{$\begin{array}{l}\text { Nonpolar } \\
\text { Neutral }\end{array}$} & $0^{A}$ & 23 & 27 & 100 & 98 \\
\hline & 15.6 & $50^{*}$ & $-^{\mathrm{C}}$ & $237^{*}$ & - \\
\hline & 31.2 & $59^{*}$ & $101^{*}$ & $292^{*}$ & $241^{*}$ \\
\hline & 62.5 & $71^{*}$ & $94^{*}$ & $387^{*}$ & $211^{*}$ \\
\hline & 125 & 34 & $135^{*}$ & $360^{*}$ & $243^{*}$ \\
\hline & 250 & - & $66^{B}$ & - & 194 \\
\hline \multirow{8}{*}{$\begin{array}{l}\text { Polar } \\
\text { Neutral }\end{array}$} & $0^{A}$ & 23 & 27 & 100 & 98 \\
\hline & 3.9 & 29 & - & - & - \\
\hline & 7.8 & 29 & - & - & 114 \\
\hline & 15.6 & 30 & 40 & 121 & 113 \\
\hline & 31.2 & 25 & 34 & 101 & 133 \\
\hline & 62.5 & - & 38 & $-{ }^{B}$ & 114 \\
\hline & 125 & - & $-^{B}$ & - & $78^{\mathrm{B}}$ \\
\hline & & & & & \\
\hline
\end{tabular}




\begin{tabular}{|c|c||c|c||c|c|}
\hline \multirow{3}{*}{$2 \mathrm{AA}$} & $0^{\mathrm{A}}$ & 23 & 27 & 100 & 98 \\
\cline { 2 - 6 } & 2.5 & - & $1595^{*}$ & - & $1974^{*}$ \\
\cline { 2 - 6 } & & & 27 & 100 & 98 \\
\hline \multirow{3}{*}{$\mathrm{N} N \mathrm{~A}$} & 23 & - & 197 & - \\
\hline
\end{tabular}

A Solvent control ${ }^{\mathrm{B}}$ Cytotoxicity ${ }^{\mathrm{C}}$ Not tested "Positive response 

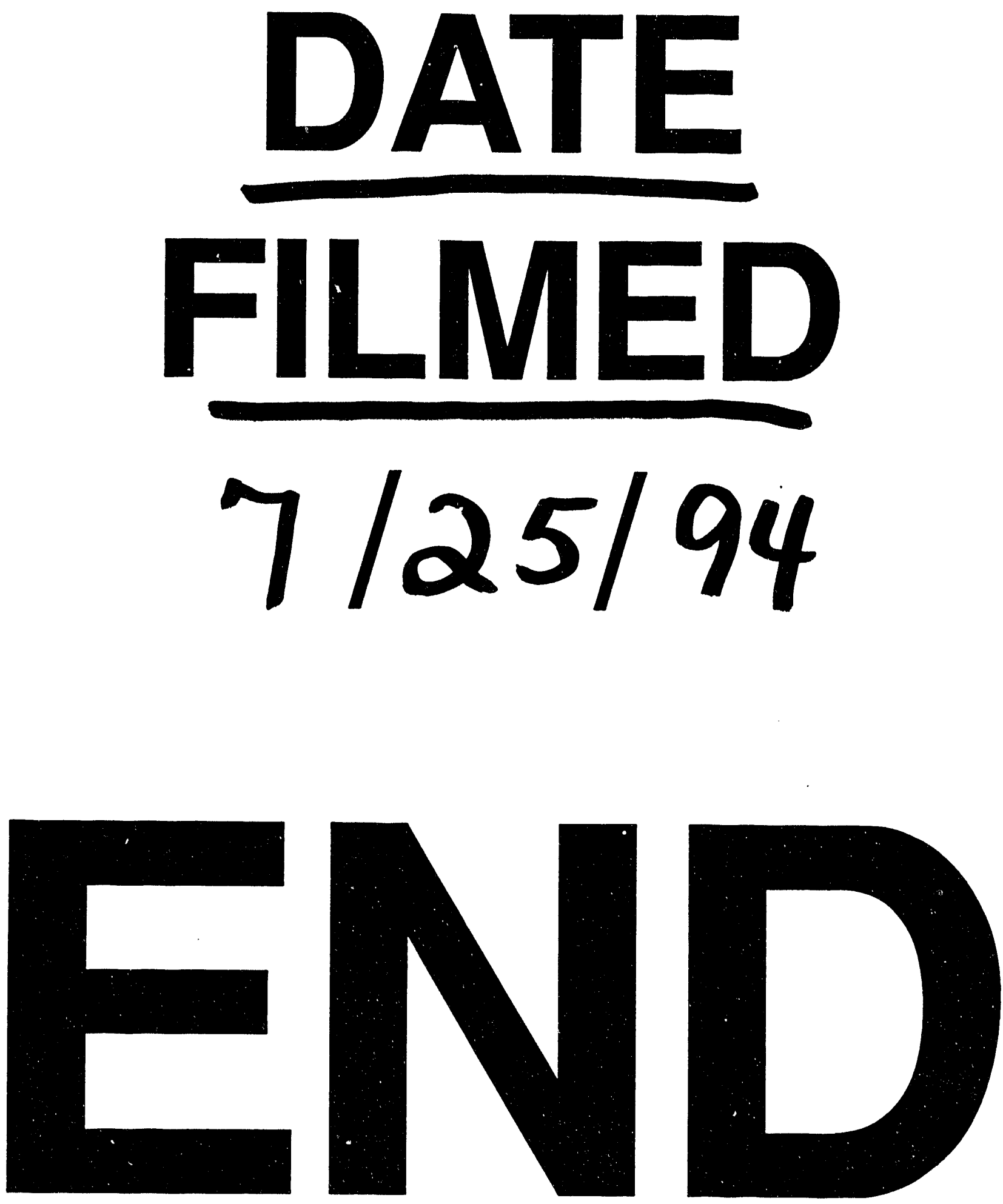
